\title{
OPTIMIZATION OF ELECTRO-FENTON OXIDATION OF CARBONATED SOFT DRINK INDUSTRY WASTEWATER USING RESPONSE SURFACE METHODOLOGY
}

\author{
Reza Davarnejad $^{1, *}$, Jamal Azizi ${ }^{1}$, Amir Joodaki ${ }^{1}$, Sepideh Mansoori ${ }^{2}$ \\ ${ }^{1}$ Department of Chemical Engineering, Faculty of Engineering, Arak University, Arak, Iran \\ ${ }^{2}$ Department of Chemical Engineering, University of Tehran, Tehran, Iran \\ r-davarnejad@araku.ac.ir
}

\begin{abstract}
The immense volume of highly polluted organic wastewater continuously generated in the beverage industry urges the design of new types of wastewater treatment plants. This study aimed to evaluate the applicability of the electro-Fenton (EF) technique to reduce organic pollution of real effluent from a carbonated soft drink factory. The impact of various process variables like $\mathrm{pH}$, time, current density, $\mathrm{H}_{2} \mathrm{O}_{2} / \mathrm{Fe}^{2+}$ molar ratio, and the volume ratio of $\mathrm{H}_{2} \mathrm{O}_{2}$ /soft drink wastewater (SDW) was analyzed using response surface methodology (RSM). The observed responses were in good agreement with predicted values obtained through optimization. The optimum conditions showed a chemical oxygen demand (COD) removal efficiency of $73.07 \%$, pH of 4.14 , time of $41.55 \mathrm{~min}$, current density of $46.12 \mathrm{~mA} / \mathrm{cm}^{2}, \mathrm{H}_{2} \mathrm{O}_{2} / \mathrm{Fe}^{2+}$ molar ratio of 0.9802 , and $\mathrm{H}_{2} \mathrm{O}_{2} / \mathrm{SDW}$ volume fraction of $2.74 \mathrm{ml} / \mathrm{l}$. The EF process was able to effectively diminish the organic pollution, reduce the residence time and, therefore, the operating costs.
\end{abstract}

Keywords: COD reduction; electro-Fenton; soft drink; wastewater

\section{ОПТИМИЗАЦИЈА НА ФЕНТОНОВА ЕЛЕКТРООКСИДАЦИЈА НА ОТПАДНИ ВОДИ ОД ИНДУСТРИЈАТА ЗА ПРОИЗВОДСТВО НА ГАЗИРАНИ ПИЈАЛАЦИ СО МЕТОДОТ НА ПОВРШИНСКА РЕАКЦИЈА}

\begin{abstract}
Огромни количества со органски супстанци силно загадена отпадна вода од индустријата за безалкохолни пијалаци наложува развивање нови пристапи кон нејзино третирање. Целта на оваа студија е да се евалуира применливоста на Фентонова електротехника (EF) за намалување на органското загадување во реални ефлуенти од фабрика за газирани пијалаци. Беше анализирано влијанието на разни параметри врз процесот како што се $\mathrm{pH}$, време, густина на струја, моларен однос на $\mathrm{H}_{2} \mathrm{O}_{2} / \mathrm{Fe}^{2+}$, како и волуменски однос $\mathrm{H}_{2} \mathrm{O}_{2} /$ отпадна вода од газирани пијалаци (SDW) co методот на површинска реакција (RSM). Добиените одговори беа во добра согласност со предвидените вредности добиени со оптимизација. Оптималните услови покажаа ефикасност на намалување на хемиски потребениот кислород (COD) на 73,07 \%, pH на 4,14, време на 41,55 min, густина на струја на $46,12 \mathrm{~mA} / \mathrm{cm}^{2}$, моларен однос на $\mathrm{H}_{2} \mathrm{O}_{2} / \mathrm{Fe}^{2+}$ на 0,9802 и волуменски удел на $\mathrm{H}_{2} \mathrm{O}_{2} / \mathrm{SDW}$ на $2,74 \mathrm{ml} / \mathrm{l}$. Електропроцесот овозможува ефикасно да се намали органското загадување, да се намали времетраењето, а со тоа и оперативните трошоци.
\end{abstract}

Клучни зборови: намалување на COD; Фентонова електрооксидација; газирани пијалаци; отпадна вода

\section{INTRODUCTION}

The beverage industry is well-known for its immense water consumption and discharge. More than $50 \%$ of the total water used in the production lines ends up as wastewater and effluent contaminated by chemical oxygen demand (COD), biochemical oxygen demand (BOD), total dissolved solids (TDS), and total suspended solids (TSS) [1]. Since caustic soda is generally used to wash the bot- 
tles, wastewater discharged from beverage industries is also reported to have high $\mathrm{pH}$ levels [2]. Considering the huge amount of wastewater produced by beverage factories worldwide, this high level of contamination is now a serious environmental concern. Therefore, the majority of beverage factories are moving towards recycling the generated wastewater in their units and reusing treated water [3]. Among various types of wastewater treatment approaches, biological treatment (aerobic and anaerobic) is frequently used in beverage and fruit concentrate factories, by converting carbonates (fructose, sugar and alcohol) to biogases [4]. Despite their widespread application, biological treatments of soft drink effluents are time-consuming, multi-stage processes, which can be accomplished only through a sequence of treating operations [5]. Shelden et al. applied a four-stage anaerobic/aerobic membrane bioreactor to treat wastewater of a soft drink industry polluted by caustic soda and successfully removed up to $95 \%$ of the COD with a hydraulic retention time of $12 \mathrm{~h}$. However, the high concentration of refractory organic pollutants and ammonium is another factor restricting the correct operation of biological sewage treatment plants [6]. Other methods for soft drink plant wastewater treatments include flocculation, chemical oxidation, ozonation, chlorination and adsorption by activated carbon [7].

According to the literature, advanced oxidation processes (AOPs) can reduce or even entirely destroy organic compounds from wastewaters, especially when the BOD/COD ratio is less than one [8]. Few studies have investigated the application of AOPs to treat effluents discharged from beverage industries. Linares Hernández et al. incorporated two AOPs (electro-coagulation by copper electrodes and electro-oxidation by a boron-doped diamond (BDD) anode and copper cathode) to reduce the concentration of pollutants in terms of COD and TOC from soft drink wastewater (SDW) containing contaminant from sanitation and backwash of the instruments. The coupled system eliminated COD by $85 \%$, biochemical oxygen demand (BOD) by 75 $\%$, and, simultaneously, reduced the operating costs and residence time [9]. Other types of AOPs, such as photolytic and photocatalytic treatments in presence of microwaves [10], photo-Fenton degradation [11], and solar-photo-Fenton treatment [12], have also proven to be effective in the decontamination of beverage industry wastewater.

The electro-Fenton $(\mathrm{EF})$ process, one AOP, is presently a highly attractive subject as a powerful technique to effectively eliminate recalcitrant organic pollutants from various kinds of wastewater. The generation of strong oxidizing $\bullet \mathrm{OH}$ radicals in the reaction environment, which are formed by the reaction between electro-generated hydrogen peroxide $\left(\mathrm{H}_{2} \mathrm{O}_{2}\right)$ catalyzed by iron ions (Equations 1-3), is the foundation of the EF process [13].

$$
\begin{gathered}
\mathrm{O}_{2}+2 \mathrm{H}^{+}+2 \mathrm{e}^{-} \rightarrow \mathrm{H}_{2} \mathrm{O}_{2} \\
\mathrm{Fe}^{2+}+\mathrm{H}_{2} \mathrm{O}_{2} \rightarrow \mathrm{Fe}^{3+}+\cdot \cdot \mathrm{OH}+\mathrm{OH}^{-} \\
\mathrm{Fe}^{3+}+\mathrm{e}^{-} \rightarrow \mathrm{Fe}^{2+}
\end{gathered}
$$

Generated hydroxyl radicals attack organic molecules and convert them into biodegradable materials, such as $\mathrm{CO}_{2}$ and $\mathrm{H}_{2} \mathrm{O}$ [14]. The EF process requires a short contact time, corroborating its economic justification. Moreover, there are further advantages, such as biocompatibility, versatility, controllability, and high decomposition rate of organic compounds, because of the continual regeneration of $\mathrm{Fe}^{2+}$ on the surface of the cathode, which reduces the sludge production content in this process [15]. Despite its great potential window for purification of various kinds of wastewater, including alcoholic, shale gas, dairy, landfill leachate, textile industry, and pharmaceutical wastewaters [16], to date, this method has not been applied to treat effluents of soft drink wastewater.

Therefore, the present study examines the applicability of the EF process to efficiently remove organic contaminants from a real soft drink factory's wastewater. Response surface methodology (RSM) with Box-Behnken design (BBD) was applied to interpret the influence of significant variables, including $\mathrm{pH}$, time, current density, $\mathrm{H}_{2} \mathrm{O}_{2} / \mathrm{Fe}^{2+}$ molar ratio, and volume ratio of $\mathrm{H}_{2} \mathrm{O}_{2} / \mathrm{SDW}$, on the removal efficiency of COD from wastewater.

\section{MATERIALS AND METHODS}

\subsection{Wastewater sampling and characterization}

The SDW sample was obtained from effluent of the Zamzam soft drink factory (Tehran, Iran) that produces carbonated soft drinks, mineral water, and non-alcoholic malt beverages. The effluent was transferred to the Research Laboratory of Chemical Engineering at Arak University and was placed in a $4{ }^{\circ} \mathrm{C}$ refrigerator before use. The wastewater possessed a $\mathrm{pH}$ of 8.4, initial COD of $508 \mathrm{mg} / \mathrm{l}$, and $\mathrm{BOD}_{5} / \mathrm{COD}$ ratio of 0.748 .

\subsection{EF reactor experimental set-up}

EF of SDW was conducted with a laboratory scale batch reactor. The experimental setup was composed of three main parts, including a direct 
current (DC) power supply (Kala Gostaran-e-Farda supplier, $30 \mathrm{~V}$ and $3 \mathrm{~A}$ ), a digital magnetic mixer, and a cylindrical glass with a volume of $250 \mathrm{ml}$, as the reactor having two parallel ferrous electrodes with a surface area of $1 \mathrm{~cm}^{2}(2 \times 0.5 \mathrm{~cm})$. The distance between the electrodes was held at $3 \mathrm{~cm}$. The initial $\mathrm{pH}$ was regulated at the desired value with $0.01 \mathrm{M} \mathrm{H}_{2} \mathrm{SO}_{4}$ (99.99\% Sigma-Aldrich) or $\mathrm{NaOH}$ (99\%, Merck Co., Darmstadt, Germany) and was measured using a $\mathrm{pH}$ meter (METTLER-TOLEDO 320) before the Fenton reagents were added. For each experiment, the desired quantity of iron salt $\left(\mathrm{FeSO}_{4} \cdot 7 \mathrm{H}_{2} \mathrm{O}\right.$, provided by Merck Co., Darmstadt, Germany) and $\mathrm{H}_{2} \mathrm{O}_{2}$ (provided by Merck Co., Darmstadt, Germany, $30 \%$ purity) were poured into the reactor. The solution was constantly homogenized at $400 \mathrm{rpm}$ by a magnetic stirrer to provide a uniform concentration in the electrolyte solution. All experiments were accomplished under ambient temperature $\left(25^{\circ} \mathrm{C} \pm 5^{\circ} \mathrm{C}\right)$. When the reaction time was completed, the DC power supply was turned off, and the solid sediments in the sample were allowed to deposit over $30 \mathrm{~min}$. The COD concentrations in the final samples were analyzed using a UV-vis spectrophotometer (DR 5000, Hach, USA) with the standard method (wavelength of $238 \mathrm{~nm}$ ). Following each test, the cathode and anode were thoroughly washed by immersion in distilled water to eliminate the deposited sediments on their surfaces.

\subsection{Design of statistical experiments}

In this study, Design-Expert software (12.0.0) was used to design, model, and optimize experiments by BBD under RSM. A five-factor and three-level BBD, including 46 experiments (6 repeats at the center point), was applied. The sequence of the experimental runs was selected on a random basis to diminish the impact of unexplained variability on the observed response. The design variables were $\mathrm{pH}$, time, current density, $\mathrm{H}_{2} \mathrm{O}_{2} / \mathrm{Fe}^{2+}$ molar ratio, and volume ratio of $\mathrm{H}_{2} \mathrm{O}_{2} / \mathrm{SDW}$, while the response variable was COD removal percentage, obtained from the following equation:

$$
\operatorname{Removal}(\%)=\frac{C_{\mathrm{i}}-C_{\mathrm{o}}}{C_{\mathrm{i}}}
$$

where $C_{\mathrm{i}}$ and $C_{\mathrm{o}}$ are initial and final CODs of the effluent, before and after the EF process, respectively. Table 1 represents the independent operational parameters and their coded levels. Effluent volume (based on the apparatus design, $250 \mathrm{ml}$ ), temperature $\left(25 \pm 0.5^{\circ} \mathrm{C}\right)$, mixing rate (without vortex observation, $400 \mathrm{rpm}$ ), electrode material (iron), electrode spacing $(3 \mathrm{~cm})$, and cross-sectional area of the electrodes $(1 \mathrm{~cm})$ were fixed as constant parameters.

Table 1

Levels of process parameters applied in experiments

\begin{tabular}{ccccc}
\hline \multirow{2}{*}{ Symbol } & Operational parameter & \multicolumn{3}{c}{ Coded levels } \\
\cline { 3 - 5 } & $\mathrm{pH}$ & 2 & 0 & +1 \\
\hline $\mathrm{A}$ & Reaction time $(\mathrm{min})$ & 10 & 4 & 6 \\
$\mathrm{~B}$ & $\mathrm{Current}$ density $\left(\mathrm{mA} / \mathrm{cm}^{2}\right)$ & 20 & 45 & 80 \\
$\mathrm{C}$ & $\mathrm{H}_{2} \mathrm{O}_{2} / \mathrm{Fe}^{2+}$ molar ratio & 0.5 & 2.25 & 70 \\
$\mathrm{D}$ & $\mathrm{H}_{2} \mathrm{O}_{2} / \mathrm{SDW}$ volume ratio $(\mathrm{ml} / \mathrm{l})$ & 0.5 & 1.75 & 4 \\
$\mathrm{E}$ & & &
\end{tabular}

\section{RESULTS AND DISCUSSION}

\subsection{Statistical analysis}

A quadratic polynomial regression model (Equation 5) was applied to estimate the behavior of system response and predict coefficients.

$$
Y=\beta_{0}+\sum_{i=1}^{k} \beta_{i} X_{i}+\sum_{i=1}^{k} \beta_{i i} X_{i}^{2}+\sum_{\substack{i=1 \\ i<j}}^{k-1} \sum_{j=2}^{k} \beta_{j i} X_{i} X_{j}+\varepsilon
$$

$\mathrm{Y}$ represents the response (percentage of COD removal efficiency). $\beta_{0}, \beta_{i}, \beta_{i i}$, and $\beta_{j i}$ are the regression coefficients for the intercept, linear, quadratic, and interaction terms, respectively. $X_{i}$ and $X_{j}$ are representative of the coded value of independent factors, and $\varepsilon$ emerges as the random error term. As determined by analysis of variance (ANOVA), all five independent parameters, as well as their interactions, significantly affected COD removal through the EF process of SDW. Figure 1 compares the anticipated and empirical data. The precision 
and validity of the model are examined by the figure slope (when it is close to one). As seen, the graph shows a proper correlation between the experimental results and the predicted ones obtained from the statistical method. Fig. 2. illustrates the normal probability graph, which indicates that the points follow nearly linear behavior. The uniformity and linearity of the points represent the normal distribution of errors, which validates the model accuracy.

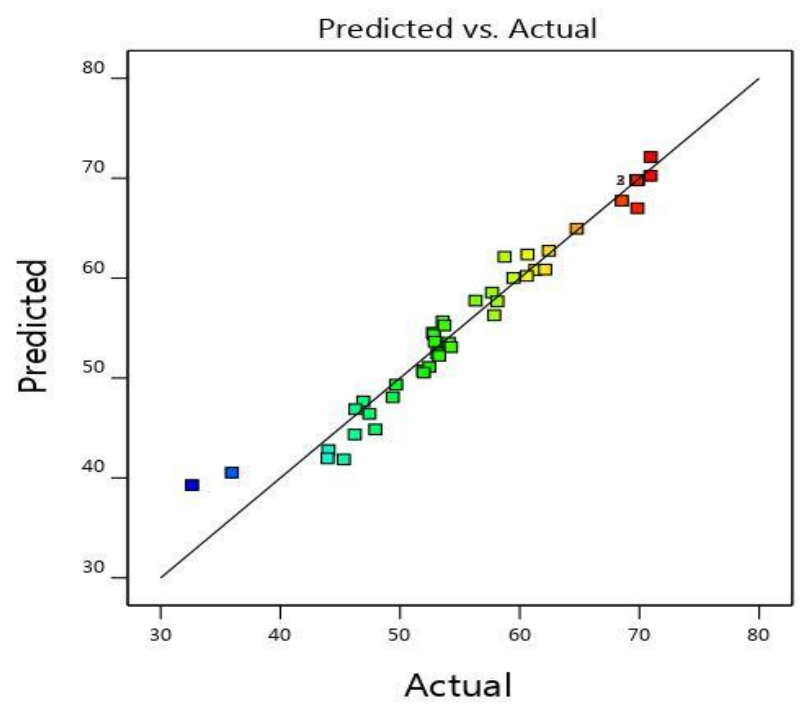

Fig. 1. Comparison of observed data for COD removal efficiency with the predicted values obtained from model

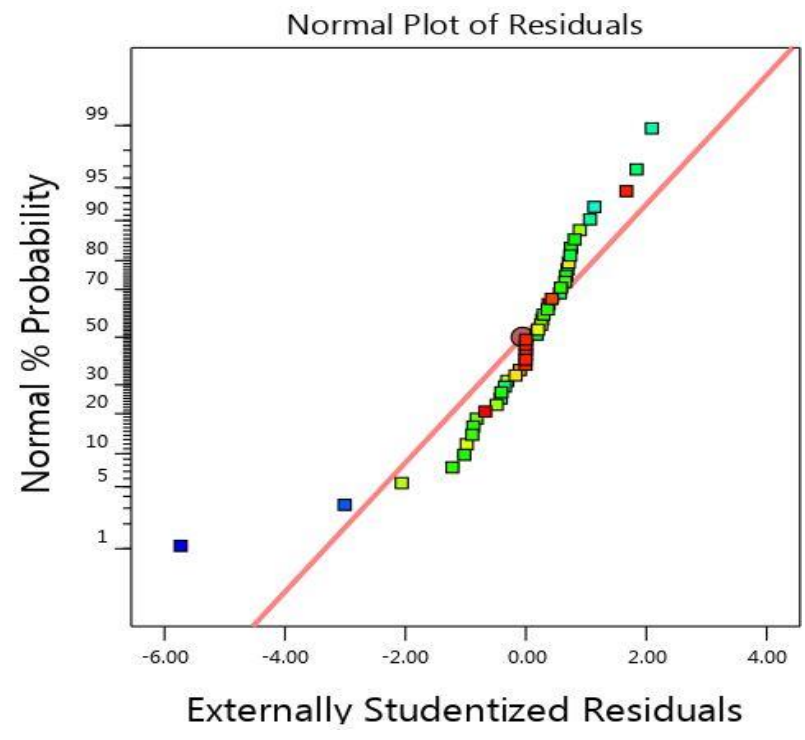

Fig. 2. Normal probability diagram for COD removal

The second-order polynomial equation for COD removal percentage was found as:

COD Removal $=69.81+5.13 \mathrm{~A}-8.6 \mathrm{~B}+5.04 \mathrm{C}-$ $1.54 \mathrm{D}-5.26 \mathrm{E}-1.85 \mathrm{AB}-1.87 \mathrm{AC}-0.9425 \mathrm{AD}-$

$$
\begin{gathered}
2.19 \mathrm{BC}-4.35 \mathrm{BD}-2.94 \mathrm{BE}+0.0025 \mathrm{CD}- \\
0.665 \mathrm{CE}-0.8025 \mathrm{DE}-9.43 \mathrm{~A}^{2}-5.7 \mathrm{~B}^{2}-7.8 \mathrm{C}^{2}- \\
7.76 \mathrm{D}^{2}-8.02 \mathrm{E}^{2}
\end{gathered}
$$

where $\mathrm{A}, \mathrm{B}, \mathrm{C}, \mathrm{D}$ and $\mathrm{E}$ are initial $\mathrm{pH}$, time, current density, $\mathrm{H}_{2} \mathrm{O}_{2} / \mathrm{Fe}^{2+}$ molar ratio, and volume ratio of $\mathrm{H}_{2} \mathrm{O}_{2} / \mathrm{SDW}$, respectively. The data for the statistical analysis of the fitted model are listed in Table 2. As shown in this table, the reported data indicate suitability of the model. The values of $\mathrm{R}^{2}, \mathrm{R}^{2}$ adjusted, and $\mathrm{R}^{2}$ were close to 1 , indicating an acceptable degree of correlation between the experimental and model data. The model possessed a high F-value (32.48) and a very low $p$-value $(<0.0001)$, suggesting that the response variability is explained by the regression analysis [17]. The coefficient of variation (CV) indicates the relative standard deviation. A low CV in Table 2 authenticates the validation of the quadratic model.

Table 2

Quadratic model ANOVA results from responses

\begin{tabular}{cc}
\hline \hline Variable & Value \\
\hline Standard deviation & 48.2 \\
Mean & 34.56 \\
$\mathrm{R}^{2}$ & 96.29 \\
$\mathrm{R}^{2}$ adjusted & 93.33 \\
$\mathrm{R}^{2}$ predicted & 85.18 \\
C.V.\% & 40.4 \\
Adequate precision (AP) & 19.6127 \\
F-value & 32.48 \\
P-value & $<0.0001$ \\
\hline \hline
\end{tabular}

\subsection{Effect of operational parameters on the EF process}

\subsection{1. $p H$ influence}

$\mathrm{pH}$ is considered one of the primary factors affecting the efficiency of the EF process. In this work, the effect of $\mathrm{pH}$ variation between 2-6 was explored. Figure 3(a) represents the effect of initial $\mathrm{pH}$ on the COD removal. As reflected in this figure, the COD removal efficiency initially increased (up to the optimum value of 4.14) and, then, decreased with increasing $\mathrm{pH}$. Even though the presence of protons in the aqueous environment had a positive effect on the electro-generation of $\mathrm{H}_{2} \mathrm{O}_{2}$, the COD removal percentage was not significant in highly acidic environments. This pattern can be explained by the production of the oxonium ion (e.g. $\mathrm{H}_{3} \mathrm{O}_{2}{ }^{+}$, Equation 7) at lower $\mathrm{pH}$ values, which stabilizes 
$\mathrm{H}_{2} \mathrm{O}_{2}$ molecules. Additionally, the higher concentration of this cation in highly acidic solution $(\mathrm{pH}<$ 2) interrupts the hydroxylation reactions by protecting the aromatic ring substituents against electrophilic attack [18]. Similar results were investigated in the EF oxidation of biologically-treated coking wastewater by Zhu et al. According to the results, the EF process showed the best oxidative performance at a $\mathrm{pH}$ of 4 . In fact, the speciation of iron and the production of $\mathrm{Fe}(\mathrm{OH})_{2}$ with higher catalytic activity than $\mathrm{Fe}^{2+}$ is the main reason for this phenomenon [19].

$$
\mathrm{H}_{2} \mathrm{O}_{2}+\mathrm{H}^{+} \rightarrow \mathrm{H}_{3} \mathrm{O}_{2}+
$$

On the opposite side, at $\mathrm{pH}$ values greater than the optimum (4.14), the decomposition of $\mathrm{H}_{2} \mathrm{O}_{2}$ into oxygen and water molecules, as well as a reduction in the oxidation potential of ${ }^{\circ} \mathrm{OH}$, results in a decreased removal efficiency [20]. This agrees with previous studies on the EF oxidation of other kinds of wastewaters. For instance, Kurt et al. treated tannery industry wastewater using the EF process and achieved $72 \%$ COD removal within the first $10 \mathrm{~min}$ of reaction under acidic conditions. In neutral $\mathrm{pH}$ conditions, the presence of undesirable side reactions caused the efficiency of COD removal to drop to 58 $\%$ during the same reaction period [21]. In another study, Ogbiye et al. investigated the significance of $\mathrm{pH}$ on the treatment efficiency of brewery industry effluent. According to experimental results, $\mathrm{pH}$ directly influenced the treatment efficiency, and the COD value was the lowest at a $\mathrm{pH}$ of 6 (the optimum value for $\mathrm{pH}$ ) [22].

\subsubsection{Reaction time influence}

Reaction time is one of the determinant factors in economic feasibility of the EF operation. Figure 3(b) shows that reaction time has a favorable effect on COD reduction through the EF process; although, this decreases with time increment. The process does not considerably change with time after the optimal value. COD removal increased with a reaction time of $41.55 \mathrm{~min}$ due to completion of oxidation over time. However, a further increase in the amount of reaction time was detrimental. This can be explained by the acceleration of $\mathrm{H}_{2} \mathrm{O}_{2}$ degradation, along with the combination of $\bullet \mathrm{OH}$ radicals, caused by a higher generation of $\mathrm{H}_{2} \mathrm{O}_{2}$ [23]. Similar results were found for EF oxidation of fruit juice production wastewater. The COD removal efficiency sharply increased within the first $60 \mathrm{~min}$ of reaction, while holding the current density (200 $\mathrm{A} / \mathrm{m}^{2}$ ) constant and the initial $\mathrm{pH}$ at 6 . Yet, only a
$10 \%$ improvement was obtained in COD elimination when the reaction was continued for an extra $300 \mathrm{~min}$ [24]. Since reaction time directly influences the expenditure of the operation, an excessive increase in the EF period is not justified from an economic point of view.

\subsubsection{Current density influence}

Since the applied current determines the electrochemical reaction rate, along with the energy consumption of the process, it is crucial to scrutinize its impact on the efficiency of the process. Moreover, current density controls the amount of generated $\bullet \mathrm{OH}$ through reactions (1) and (3) [25]. Figure 3(c) indicates the impact of applied current density on the COD elimination efficiency. The COD degradation rate rises to the optimum value as current density grows, which is chiefly related to the high-speed generation of $\mathrm{H}_{2} \mathrm{O}_{2}$ and $\mathrm{Fe}^{2+}$ at higher current values [26]. No further increase in COD removal percentage was noticed for applied current densities greater than $46.12 \mathrm{~mA} / \mathrm{cm}^{2}$, owing to the domination of some unwanted side reactions. Excessive current density favors the four-electron pathway for oxygen reduction (Equation 8) over the production of hydrogen peroxide and also drives the formation of $\mathrm{H}_{2}$ (Equation 9). This also enhances the risk of hydrogen peroxide and $\mathrm{H}_{2} \mathrm{O}_{2}$ involvement in parasitic reactions (Equations 10-12) [27].

$$
\begin{gathered}
\mathrm{O}_{2}+4 \mathrm{e}^{-}+4 \mathrm{H}^{+} \rightarrow 2 \mathrm{H}_{2} \mathrm{O} \\
2 \mathrm{e}^{-}+2 \mathrm{H}^{+} \rightarrow \mathrm{H}_{2} \\
\mathrm{Fe}^{2+}+{ }^{\cdot} \mathrm{OH} \rightarrow \mathrm{Fe}^{3+}+\mathrm{OH}^{-} \\
2^{\cdot} \mathrm{OH} \rightarrow \mathrm{H}_{2} \mathrm{O}_{2} \\
\cdot \mathrm{OH}+\mathrm{H}_{2} \mathrm{O}_{2} \rightarrow{ }^{\circ} \mathrm{O}_{2} \mathrm{H}+\mathrm{H}_{2} \mathrm{O}
\end{gathered}
$$

The results of our previous study on the EF degradation of dairy wastewater also showed that an enhancement of current density from 20 to 56 $\mathrm{mA} / \mathrm{cm}^{2}$ augmented the degradation of COD in the wastewater. Although, further increase in the current density slightly reduced the removal efficiency [28]. The ideal value for current density in EF purification of the grey wastewater was found to be 10 $\mathrm{mA} / \mathrm{cm}^{2}$ by Thirugnanasambandham et al. The authors explained that the four-electron reduction of oxygen and hydrogen production reactions are responsible for the reduction in the process efficiency at current densities beyond the optimum value. Therefore, for the best treatment efficiency and economic productivity, it is essential to find the optimum current density [29]. 


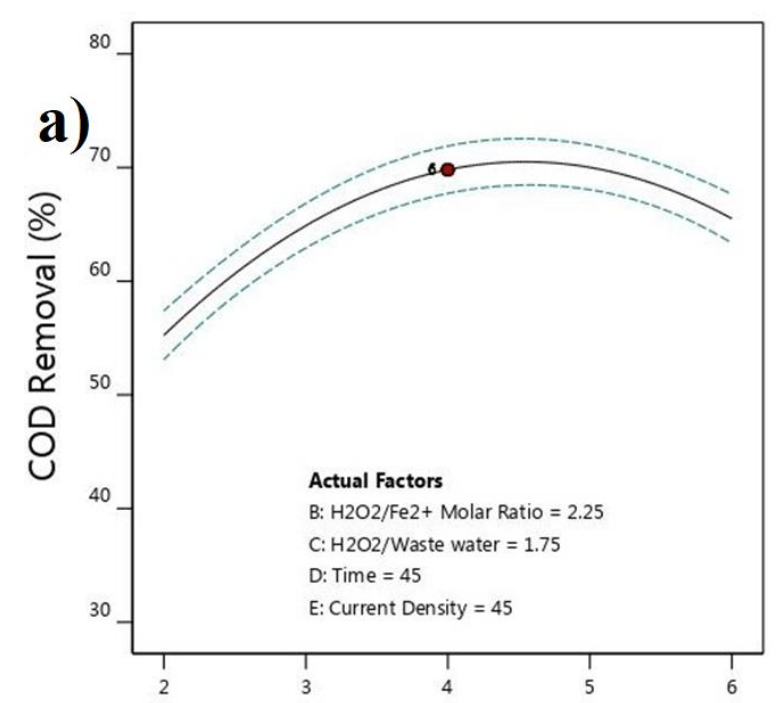

$\mathrm{A}: \mathrm{pH}$

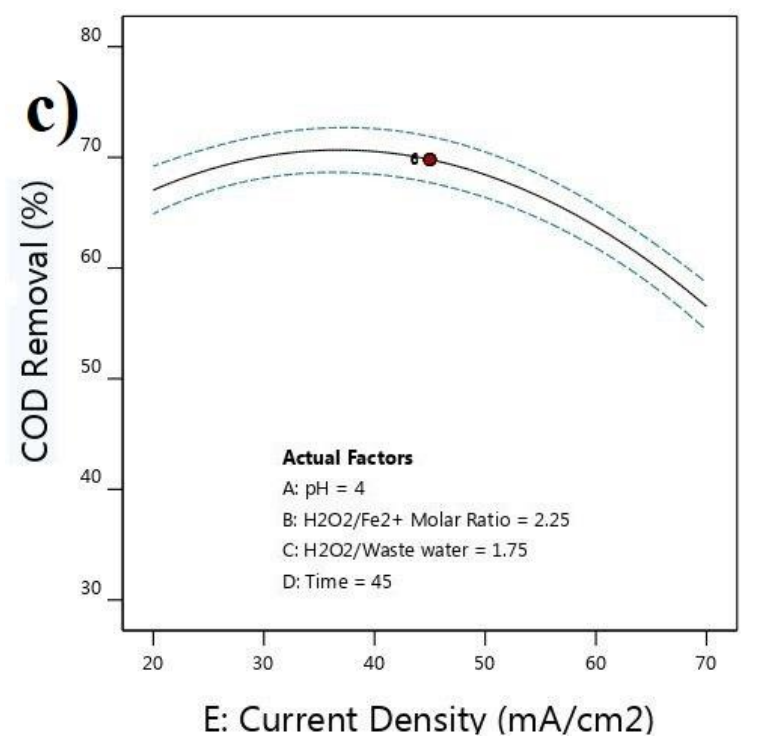

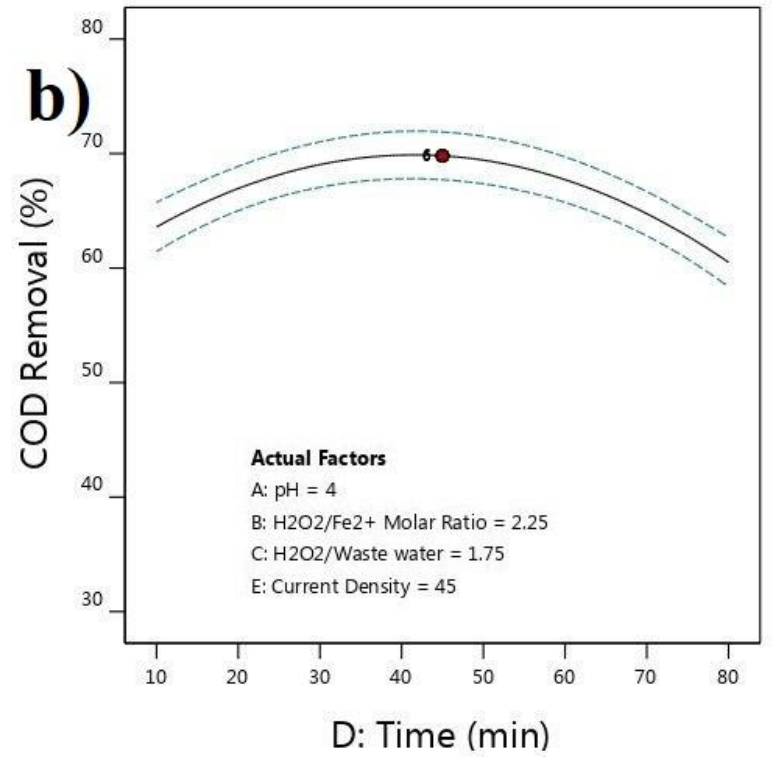

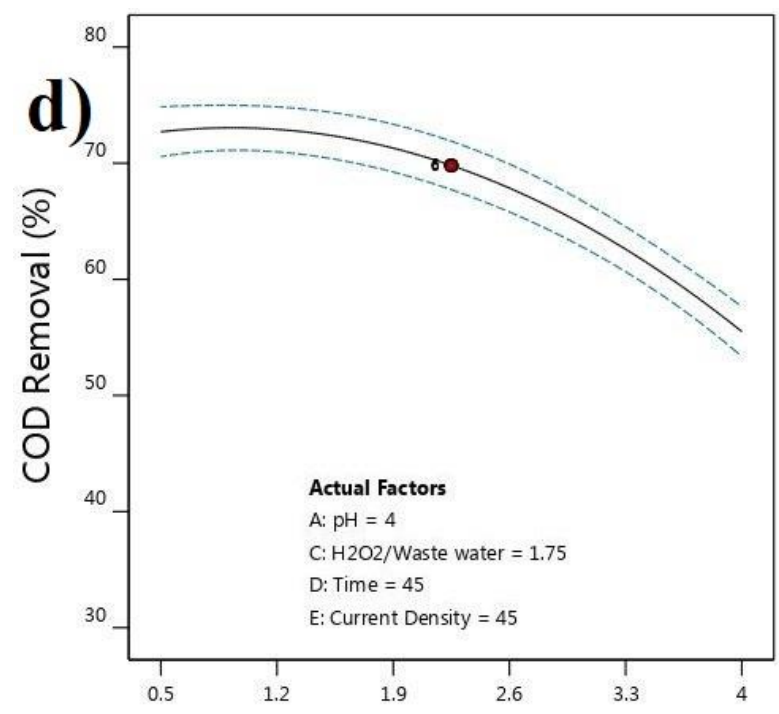

B: $\mathrm{H} 2 \mathrm{O} 2 / \mathrm{Fe} 2+$ Molar Ratio

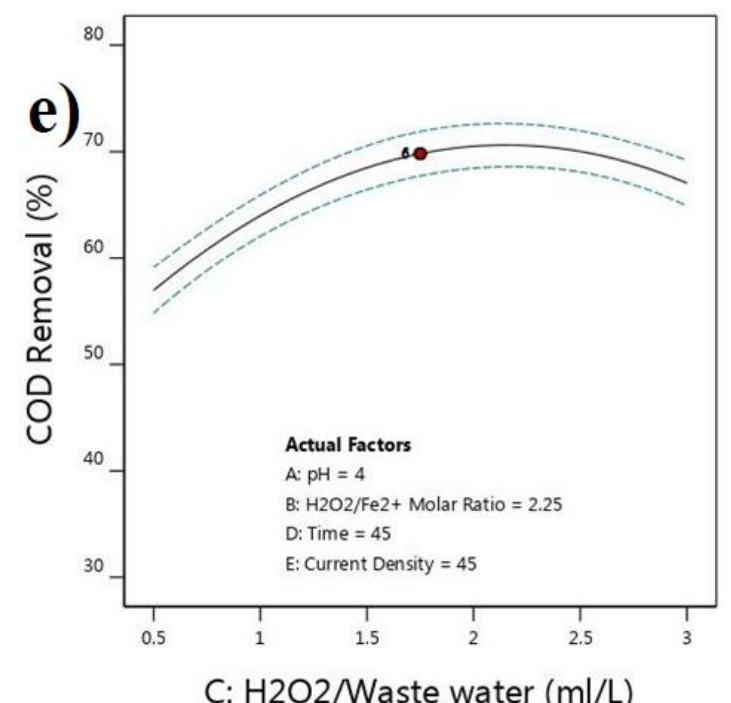

Fig. 3. a) Impact of $\mathrm{pH}$ on COD removal. b) Impact of reaction time on COD removal. c) Impact of current density on COD removal. d) Impact of $\mathrm{H}_{2} \mathrm{O}_{2} / \mathrm{Fe}^{2+}$ molar ratio effect on COD removal. e) Impact of volume fraction of $\mathrm{H}_{2} \mathrm{O}_{2} / \mathrm{SDW}(\mathrm{ml} / \mathrm{l})$ on COD removal 


\subsubsection{Influences of $\mathrm{H}_{2} \mathrm{O}_{2} / \mathrm{Fe}^{2+}$ molar ratio and $\mathrm{H}_{2} \mathrm{O}_{2} / S D W$ volume ratio}

The $\mathrm{H}_{2} \mathrm{O}_{2} / \mathrm{Fe}^{2+}$ molar ratio and volume ratio of $\mathrm{H}_{2} \mathrm{O}_{2} / \mathrm{SDW}$ have significant contributions to COD elimination from wastewater. As shown in Figures 3(d) and 3(e), the enhancement of the $\mathrm{H}_{2} \mathrm{O}_{2} / \mathrm{Fe}^{2+}$ molar ratio and volume ratio of $\mathrm{H}_{2} \mathrm{O}_{2} / \mathrm{SDW}$ (up to 0.9802 and $2.74 \mathrm{ml} / \mathrm{l}$, respectively) positively influenced COD removal, owing to the increased generation of hydroxyl radicals as oxidizing agents. Nonetheless, additional growth in the $\mathrm{H}_{2} \mathrm{O}_{2} / \mathrm{Fe}^{2+}$ molar ratio and volume ratio of $\mathrm{H}_{2} \mathrm{O}_{2} / \mathrm{SDW}$ dwindled COD removal due to the acceleration of parasitic reactions that scavenge hydroxyl radicals. Similar results were found in the literature. Akkaya et al. suggested low $\mathrm{H}_{2} \mathrm{O}_{2} / \mathrm{COD}$ ratios (optimum value at 1.9) in order to achieve better results in the COD removal from dairy wastewater [30]. Ghoneim et al. reported that oxidation only occurs with hydroxyl radical production at the cathode or $\mathrm{HO}_{2}$ production at the anode by $\mathrm{H}_{2} \mathrm{O}_{2}$ decomposition. Furthermore, considerable oxidation can be observed by increasing the $\mathrm{Fe}^{2+}$ ion concentration. Although, oxidation decreases at high $\mathrm{Fe}^{2+}$ concentrations [31]. This may be due to the inhibition of hydroxyl radicals by $\mathrm{Fe}^{2+}$ ions. The formed $\mathrm{Fe}^{3+}$ ions can also react with $\mathrm{H}_{2} \mathrm{O}_{2}$ to produce $\mathrm{HO}_{2}{ }^{*}$, which reduces the oxidation process [32].

\subsection{Optimization procedure}

Optimization of the contributing variables is an essential step to evaluating the practical application of the process. Hence, in this research, numerical optimization was conducted by the BBD model. The optimum levels of independent parameters were found to be a $\mathrm{pH}$ of 4.14 , time of $41.55 \mathrm{~min}$, current density of $46.12 \mathrm{~mA} / \mathrm{cm}^{2}, \mathrm{H}_{2} \mathrm{O}_{2} / \mathrm{Fe}^{2+}$ molar ratio of 0.9802 and $\mathrm{H}_{2} \mathrm{O}_{2} / \mathrm{SDW}$ volume fraction of $2.74 \mathrm{ml} / \mathrm{l}$. Under these conditions, a COD removal of $73.07 \%$ was obtained. The actual COD removal percentage, obtained by conducting experiments under optimized conditions, was $72.17 \%$, which agreed well with the model prediction.

Compared with other types of beverage industry wastewater treatment techniques (shown in Table 3), the EF process applied in the present study exhibited acceptable COD removal efficiency within a shorter time period, which is of great importance for economic and practical application on a large scale.

T a ble 3

Comparison of the beverage industry wastewater treatment efficiency by various methods

\begin{tabular}{|c|c|c|c|c|c|c|}
\hline \multirow{2}{*}{ Treatment approach } & \multirow{2}{*}{$\begin{array}{l}\text { Removal } \\
\text { efficiency }\end{array}$} & \multirow{2}{*}{$\begin{array}{l}\text { Treatment } \\
\text { period }\end{array}$} & \multicolumn{3}{|c|}{$\begin{array}{c}\text { Characterization of the beverage } \\
\text { wastewater }\end{array}$} & \multirow[b]{2}{*}{ Reference } \\
\hline & & & $\begin{array}{l}\mathrm{COD} \\
(\mathrm{mg} / \mathrm{l})\end{array}$ & $\mathrm{pH}$ & $\mathrm{BOD}_{5} / \mathrm{COD}$ & \\
\hline $\begin{array}{l}\text { Electrocoagulation - Electro } \\
\text { oxidation }\end{array}$ & $85 \%$ of COD & $12 \mathrm{~h}$ & 4300 & 11.3 & 0.436 & {$[10]$} \\
\hline A single photo-Fenton & $53 \%$ of TOC & $2 \mathrm{~h}$ & 3410 & 4.89 & - & {$[12]$} \\
\hline Photo-Fenton/persulfate & $76 \%$ of COD & $4 \mathrm{~h}$ & 5510 & 6.25 & 0.374 & [12] \\
\hline Solar-photo-Fenton & $100 \%$ of COD & $125 \mathrm{~min}$ & 6500 & 5.35 & 0.677 & {$[13]$} \\
\hline Membrane bioreactor (MBR) & $94 \%$ of COD & $5-12 \mathrm{~h}$ & 772 & 7.06 & 0.300 & {$[33]$} \\
\hline Activated sludge & $43 \%$ of COD & $5-12 \mathrm{~h}$ & 772 & 7.06 & 0.300 & {$[33]$} \\
\hline Upflow anaerobic sludge & $80 \%$ of COD & $6-9 \mathrm{~h}$ & $<600$ & $6-9$ & 0.500 & [34] \\
\hline $\begin{array}{l}\text { Coagulant polyaluminum } \\
\text { chloride-ozone }\end{array}$ & $17 \%$ of COD & $1 \mathrm{~h}$ & 3410 & 4.89 & - & {$[35]$} \\
\hline $\begin{array}{l}\text { Electrooxidation } \\
\text { with BDD electrodes }\end{array}$ & $\begin{array}{l}98 \% \text { of COD } \\
94 \% \text { of TOC }\end{array}$ & $14 \mathrm{~h}$ & 4500 & 12 & 0.351 & {$[36]$} \\
\hline Electro-Fenton & $73.07 \% \mathrm{COD}$ & $41.55 \mathrm{~min}$ & 508 & 8.4 & 0.748 & This work \\
\hline
\end{tabular}

\section{CONCLUSIONS}

In this work, the EF process was applied for treating real wastewater obtained from a carbonated soft drink factory. BBD under RSM was employed to minimize the number of experiments and opti- mize five independent variables affecting COD removal efficiency. At its best performance, the EF process was able to remove COD of SDW by $73 \%$ within $41.55 \mathrm{~min}$, which is considerably lower than the residence time needed for conventional biological treatments. The optimum values of other parameters were found to be a $\mathrm{pH}$ of 4.14 , current density 
of $46.12 \mathrm{~mA} / \mathrm{cm}^{2}, \mathrm{H}_{2} \mathrm{O}_{2} / \mathrm{Fe}^{2+}$ molar ratio of 0.9802 , and $\mathrm{H}_{2} \mathrm{O}_{2} / \mathrm{SDW}$ volume fraction of $2.74 \mathrm{ml} / \mathrm{l}$.

\section{REFERENCES}

[1] E. Ait Hsine, A. Benhammou, M. Pons, Water resources management in soft drink industry-water use and wastewater generation, Environmental Technology, 26 (12), 1309-1316 (2005).

DOI: https://doi.org/10.1080/09593332608618605

[2] A. Swain, N. Shukla, N. Remya, Treatment of wastewater from beverage/soft drink industry by microwave photolytic process, recent developments in waste management, Springer 2020, pp. 335-343.

DOI: https://doi.org/10.1007/978-981-15-0990-2_26

[3] Y. Wang, L. Serventi, Sustainability of dairy and soy processing: a review on wastewater recycling, Journal of Cleaner Production, 237, 117821 (2019).

DOI: https://doi.org/10.1016/j.jclepro.2019.117821

[4] F. Gholami, A. Zinatizadeh, S. Zinadini, T. McKay, L. Sibali, An innovative jet loop-airlift bioreactor for simultaneous removal of carbon and nitrogen from soft drink industrial wastewater: Process performance and kinetic evaluation, Environmental Technology \& Innovation 100772 (2020).

DOI: https://doi.org/10.1016/j.eti.2020.100772

[5] A. Asadi, A. A. Zinatizadeh, M. Van Loosdrecht, A novel continuous feed and intermittent discharge airlift bioreactor (CFIDAB) for enhanced simultaneous removal of carbon and nutrients from soft drink industrial wastewater, Chemical Engineering Journal, 292, 13-27 (2016). DOI: https://doi.org/10.1016/j.cej.2016.01.110

[6] B. Saenz de Miera, A. S. Oliveira, J. Baeza, L. Calvo, J. Rodriguez, M. A. Gilarranz, Treatment and valorisation of fruit juice wastewater by aqueous phase reforming: Effect of $\mathrm{pH}$, organic load and salinity, Journal of Cleaner Production, 252, 119849 (2020).

DOI: https://doi.org/10.1016/j.jclepro.2019.119849

[7] N. Muhammad, M. Nafees, R. Hussain, M. H. Khan, S. Jehan, U. Ullah, Pollution and energy reduction strategy in soft drink industries, Environmental Science and Pollution Research, 25 (28), 28153-28159 (2018). DOI: https://doi.org/10.1007/s11356-018-2861-x

[8] R. Davarnejad, M. Mohammadi, A. F. Ismail, Petrochemical wastewater treatment by electro-Fenton process using aluminum and iron electrodes: Statistical comparison, Journal of Water Process Engineering 3, 18-25 (2014).

DOI: https://doi.org/10.1016/j.jwpe.2014.08.002

[9] I. Linares Hernández, C. Barrera Díaz, M. Valdés Cerecero, P. T. Almazán Sánchez, M. Castañeda Juárez, V. Lugo Lugo, Soft drink wastewater treatment by electrocoagulation-electrooxidation processes, Environmental Technology, 38(4), 433-442 (2017).

DOI: https://doi.org/10.1080/09593330.2016.1196740

[10] N. Remya, A. Swain, Soft drink industry wastewater treatment in microwave photocatalytic system Exploration of removal efficiency and degradation mechanism, Separation and Purification Technology, 210, 600-607 (2019).

DOI: https://doi.org/10.1016/j.seppur.2018.08.051
[11] A. J. Expósito, J. M. Monteagudo, I. Díaz, A. Durán, Photo-Fenton degradation of a beverage industrial effluent: intensification with persulfate and the study of radicals, Chemical Engineering Journal, 306 1203-1211 (2016). DOI: https://doi.org/10.1016/j.cej.2016.08.048

[12] A. Durán, J. Monteagudo, J. Gil, A. Expósito, I. San Martín, Solar-photo-Fenton treatment of wastewater from the beverage industry: Intensification with ferrioxalate, Chemical Engineering Journal, 270, 612-620 (2015). DOI: https://doi.org/10.1016/j.cej.2015.02.069

[13] P. Cao, X. Quan, K. Zhao, S. Chen, H. Yu, J. Niu, Selective electrochemical $\mathrm{H}_{2} \mathrm{O}_{2}$ generation and activation on a bifunctional catalyst for heterogeneous electroFenton catalysis, Journal of Hazardous Materials, 382, $121102(2020)$ DOI: https://doi.org/10.1016/j.jhazmat.2019.121102

[14] S. O. Ganiyu, M. Zhou, C. A. Martínez-Huitle, Heterogeneous electro-Fenton and photoelectro-Fenton processes: a critical review of fundamental principles and application for water/wastewater treatment, Applied Catalysis B: Environmental, 235, 103-129 (2018). DOI: https://doi.org/10.1016/j.apcatb.2018.04.044

[15] C. Bruguera-Casamada, R. M. Araujo, E. Brillas, I. Sirés, Advantages of electro-Fenton over electrocoagulation for disinfection of dairy wastewater, Chemical Engineering Journal, 376, 119975 (2019). DOI: https://doi.org/10.1016/j.cej.2018.09.136

[16] P. Nidheesh, R. Gandhimathi, Trends in electro-Fenton process for water and wastewater treatment: an overview, Desalination, 299, 1-15 (2012). DOI: https://doi.org/10.1016/j.desal.2012.05.011

[17] K. Thirugnanasambandham, V. Sivakumar, K. Shine, Performance evaluation of chemical coagulation process to treat bagasse wastewater: modeling and optimization, Polish Journal of Chemical Technology, 18(1), 99-104 (2016). DOI: https://doi.org/10.1515/pjct-2016-0015

[18] J. Meijide, M. Pazos, M. Á. Sanromán, Heterogeneous electro-Fenton catalyst for 1-butylpyridinium chloride degradation, Environmental Science and Pollution Research, 26(4), 3145-3156 (2019). DOI: https://doi.org/10.1007/s11356-017-0403-6

[19] X. Zhu, J. Tian, R. Liu, L. Chen, Optimization of Fenton and electro-Fenton oxidation of biologically treated coking wastewater using response surface methodology, Separation and Purification Technology, 81, 444-450 (2011). DOI: https://doi.org/10.1016/j.seppur.2011.08.023

[20] M. Sadeghi, M. H. Mehdinejad, N. Mengelizadeh, Y Mahdavi, H. Pourzamani, Y. Hajizadeh, M. R. Zare, Degradation of diclofenac by heterogeneous electroFenton process using magnetic single-walled carbon nanotubes as a catalyst, Journal of Water Process Engineering, 31, 100852 (2019).

DOI: https://doi.org/10.1016/j.jwpe.2019.100852

[21] U. Kurt, O. Apaydin, M. T. Gonullu, Reduction of COD in wastewater from an organized tannery industrial region by Electro-Fenton process, Journal of hazardous materials, 143(1-2), 33-40 (2007). DOI: https://doi.org/10.1016/j.jhazmat.2006.08.065

[22] A. S. Ogbiye, D. O. Omole, K. D. Ade-Balogun, O. Onakunle, O. O. Elemile, Treatment of brewery wastewater using electro-Fenton and granulated activated carbon, Cogent Engineering, 5(1) ,1447224 (2018). DOI: https://doi.org/10.1080/23311916.2018.1447224 
[23] R. Davarnejad, S. Nasiri, Slaughterhouse wastewater treatment using an advanced oxidation process: optimization study, Environmental Pollution, 223, 1-10 (2017). DOI: https://doi.org/10.1016/j.envpol.2016.11.008

[24] O. Can, COD removal from fruit-juice production wastewater by electrooxidation, electrocoagulation and electro-Fenton processes, Desalination and Water Treatment, 52(1-3), 65-73 (2014). DOI: https://doi.org/10.1080/19443994.2013.781545

[25] M. Panizza, M. A. Oturan, Degradation of Alizarin Red by electro-Fenton process using a graphite-felt cathode, Electrochimica Acta, 56(20), 7084-7087 (2011). DOI: https://doi.org/10.1016/j.electacta.2011.05.105

[26] B. Hou, W. Ma, H. Han, P. Xu, H. Zhuang, S. Jia, K. Li, Optimization of electro-Fenton oxidation of biologically pretreated coal gasification wastewater by response surface methodology, Desalination and Water Treatment, 57(18), 8174-8182 (2016).

DOI: https://doi.org/10.1080/19443994.2015.1018330

[27] M. Panizza, A. Barbucci, M. Delucchi, M. Carpanese, A. Giuliano, M. Cataldo-Hernández, G. Cerisola, ElectroFenton degradation of anionic surfactants, Separation and Purification Technology, 118, 394-398 (2013). DOI: https://doi.org/10.1016/j.seppur.2013.07.023

[28] R. Davarnejad, M. Nikseresht, Dairy wastewater treatment using an electrochemical method: experimental and statistical study, Journal of Electroanalytical Chemistry, 775, 364-373 (2016).

DOI: https://doi.org/10.1016/j.jelechem.2016.06.016

[29] K. Thirugnanasambandham, V. Sivakumar, Optimization of treatment of grey wastewater using Electro-Fenton technique - Modeling and validation, Process Safety and Environmental Protection, 95, 60-68 (2015). DOI: https://doi.org/10.1016/j.psep.2015.02.001

[30] G. Akkaya, H. Erkan, E. Sekman, S. Top, H. Karaman, M. Bilgili, G. Engin, Modeling and optimizing Fenton and electro-Fenton processes for dairy wastewater treatment using response surface methodology, International journal of environmental science and technology, 16(5), 192-207 (2019).

DOI: https://doi.org/10.1007/s13762-018-1846-0

[31] M. M. Ghoneim, H. S. El-Desoky, N. M. Zidan, ElectroFenton oxidation of Sunset Yellow FCF azo-dye in aqueous solutions, Desalination, 274(1-3), 22-30 (2011). DOI: https://doi.org/10.1016/j.desal.2011.01.062

[32] F. Deng, O. Garcia-Rodriguez, H. Olvera-Vargas, S. Qiu, O. Lefebvre ,J. Yang, Iron-foam as a heterogeneous catalyst in the presence of tripolyphosphate electrolyte for improving electro-Fenton oxidation capability, Electrochimica Acta, 272, 176-183 (2018). DOI: https://doi.org/10.1016/j.electacta.2018.03.160

[33] M. Matošić, I. Prstec, H. K. Jakopović, I. Mijatović, Treatment of beverage production wastewater by membrane bioreactor, Desalination, 246(1-3), 285-293 (2009). DOI: https://doi.org/10.1016/j.desal.2008.04.051

[34] U. Austermann-Haun, K.-H. Rosenwinkel, Two examples of anaerobic pre-treatment of wastewater in the beverage industry, Water Science and Technology, 36(23), 311-319 (1997).

DOI: https://doi.org/10.2166/wst.1997.0546

[35] M. García-Morales, G. Roa-Morales, C. Barrera-Díaz, P. Balderas-Hernández, Treatment of soft drink process wastewater by ozonation, ozonation- $\mathrm{H}_{2} \mathrm{O}_{2}$ and ozonationcoagulation processes, Journal of Environmental Science and Health, Part A 47(1), 22-30 (2012). DOI: https://doi.org/10.1080/10934529.2012.629575

[36] R. E. Victoria-Salinas, V. Martínez-Miranda, I. LinaresHernández, G. Vázquez-Mejía, M. Castañeda-Juárez, P. T. Almazán-Sánchez, Pre-treatment of soft drink wastewater with a calcium-modified zeolite to improve electrooxidation of organic matter, Journal of Environmental Science and Health, Part A, 54(7) 617-627 (2019). DOI: https://doi.org/10.1080/10934529.2019.1579522 
